\title{
Application of Enzyme Extracted from Aloe vera Plant in Chemical Pretreatment of Cotton Knitted Textile to Reduce Pollution Load
}

\author{
D. Jothi \\ Textile Chemistry Department, SSM, College of Engineering, Komarapalayam, India \\ Email: jothi bahirdar@yahoo.co.in, jothi.tchod@gmail.com
}

Received 3 April 2015; accepted 22 August 2015; published 25 August 2015

\begin{abstract}
Nowadays, highly alkaline chemicals like caustic soda, soda ash, silicate, acetic acid and soaping agents are used for scouring to remove the non-cellulosic impurities from the cotton. Using 30 - 40 $\mathrm{gm} / \mathrm{Kg}$ on weight of the fabric results in destruction of cotton structure. Intensive rinsing and more acid is needed for reutilization of cotton, which enlarges the volume of effluent. Furthermore, these hazards chemicals result in increase in COD, BOD and TDS in waste water. These chemicals also attack the cellulose leading to heavy strength loss and weight loss in the fabric. The net result is low quality control and polluted environment with high usage of energy, time, chemical and water. Aloe vera presents the finest commercial opportunity in various industrial sectors among the various plants. Also, most of the countries are gifted with the unique geographical features that are essential for cultivation of Aloe vera. Yet, none of the country has realized and reaped the full potential of such plants in various industrial applications. The reason is simple: lack of the requisite expertise in extraction of various enzymes present in aloe plant. Fortunately, the technology is now accessible to make use of enzyme in textile application. In this research an attempt has been made to make use of lipase enzyme extracted from aloe plant in textile chemical pretreatment process. In the present research work, an attempt was made to develop bio scouring of $100 \%$ cotton knitted fabric with lipase enzyme extracted from Aloe deberena plant at various concentration $(1 \%, 2 \%$ and $3 \%)$ at various temperature $\left(40^{\circ} \mathrm{C}, 60^{\circ} \mathrm{C}\right.$ and $\left.70^{\circ} \mathrm{C}\right)$ for a period of 30 minutes, 60 minutes and 90 minutes. The properties of bio scoured fabrics are compared with these of conventional scoured one. Encouraging results in terms of dye uptake, dye levelness, wash fastness, light fastness and rubbing fastness are obtained in case of bio scouring fabric dyed with dark reactive colors. Further, it reduces volume of effluent as well as COD, TDS and pH. It saves a substantial thermal energy $50 \%$ and electrical energy $40 \%$. Bio scouring waste water has $40 \%-50 \%$ less COD and $60 \%$ less TDS as compared to conventional scouring waste water.
\end{abstract}

\section{Keywords}

Bio-Scouring, Lipase, TDS, COD 


\section{Introduction}

The use of enzymes in the textile chemical processing is rapidly gaining global recognition because of their nontoxic and eco-friendly characteristics with the increasingly important requirements for textile manufacturers to reduce pollution in textile production. Enzymes sources, activity, specificity, reaction, mechanism and thermodynamics, function of textile processing with enzymes, major enzymatic applications in textile wet processing and promising areas of enzyme applications in textile processing are discussed. The aim is to provide the textile technologist with an understanding of enzymes and their use with textile materials [1]-[4].

Effective chemical processing of textiles requires uniform absorbency. Furthermore, no disturbing amount of added and birth impurities such as dirt, sizes materials, should remain on the fibers. Sixty percent of all the problems occurring in the dyeing and finishing of cotton originate from a wrong or uneven pre-treatment [5] [6].

Regarding the enzymatic removal of natural-adhering cotton, the degree of degradation was determined by measuring amount of reducing groups being released into the solution. The degree of whiteness after enzymatic degradation of the pectin was lower compared to alkaline boiling-off. However, combining the enzyme treatment with the alkalineboil-off would improve the whiteness of the fabric. A recent research output has strongly revealed that the degree of whiteness of a cotton sample only treated with enzymes was lower by $10 \%$ to $12 \%$ than the degree of whiteness of an alkaline boiled off material. The effect of the enzymatic treatment was also determined by measuring the wettability of pre-treated fabrics. The differences were documented by the TEGWA drop test [9].

Factors influencing scouring are the nature of the substrate, the kind of enzyme used, the enzyme activity, the use of surfactants and mechanical impact. It was observed that, during bio scouring, much less wax was removed as compared to alkaline scouring. If the treatment was combined with surfactant, results equivalent to alkaline scouring could be achieved [10] [11].

The activities of enzymes are determined by their three-dimensional structure. Most enzymes can be denatured, which disrupt the three-dimensional structure of the protein. Denaturation may be reversible or irreversible depending on the enzyme.

In 1894 Emil Fischer provided the lock-and-key model assuming that the active site was a perfect fit for a specific substrate and that once the substrate binded to the enzyme no further modification was necessary. It is a simplistic model.

In 1958 Daniel Koshland suggested a modification to the lock and key model. Instead of flexible structures, the active site is continually reshaped by interactions with the substrate as the substrate interacts with the enzyme. As a result, the substrate does not simply bind to a rigid active site; the amino acid side chains which make up the active site are molded into the precise positions that enable the enzyme to perform its catalytic function. In some cases, such as glycosidases, the substrate molecule also changes shape slightly as it enters the active site. The active site continues to change until the substrate is completely bound, at which point the final shape and charge is determined. The product is usually unstable in the active site due to steric hindrances that force it to be released and return the enzyme to its initial unbound state.

\section{Experimental Procedure}

\subsection{Materials}

Knitted fabric samples were collected from Jayavishnu Textile Processor, Tirupur, Tamilandu, India. Enzymes were supplied from Bagavathi Bio Tech Chemical Manufacturing, Chotode, Erode, Tamilnadu, India. Particulars were subjected to scouring and dyeing in winch: The chemicals and auxiliaries are used in this research is listed in Table 1.

\subsection{Sample Details}

Fabric-100\% cotton; Type: single Jersy;

GSM: 180.

\section{Methods}

\subsection{BIO Scouring-Indo Biosoft Using Bagavathi Bio Tech}

1) Recipe 
Table 1. List of chemicals and auxiliaries used.

\begin{tabular}{cccc}
\hline Sr. No & Name of chemicals \& Auxiliaries & Manufacturer & Function \\
\hline 1 & Wetting agent & Colurtex, Mumbai & Nonionic wetting \\
2 & Bio scour Enzyme (Indo Bio Soft) & $\begin{array}{c}\text { Bagathi Bio Tech chemical } \\
\text { company, Erode, India }\end{array}$ & Scouring of cotton \\
3 & Sodium hydroxide (Flakes) & Lab grade & $\begin{array}{c}\text { For conventional } \\
\text { scouring of cotton }\end{array}$ \\
4 & Hydrogen peroxide 50\% & Lab grade & $\begin{array}{c}\text { For conventional scouring of } \\
\text { cotton }\end{array}$ \\
5 & Acetic Acid & Lab grade & $\begin{array}{c}\text { For neutralization of cotton } \\
\text { after conventional scouring } \\
6\end{array}$ \\
7 & C.I Reactive Red 24 & For cotton dyeing \\
\hline
\end{tabular}

Wetting: $0.5 \%$ - $1 \%$ o.w.m (On the weight of the material);

Bio scouring enzyme $1 \%, 3 \%$, and $5 \%$ o.w.m;

Temperature: $40^{\circ} \mathrm{C}, 60^{\circ} \mathrm{C}$ and $80^{\circ} \mathrm{C}$;

PH: 5.5, 7.0 and 8.5;

Time: 30 - 45 minutes.

2) Process Sequence

Bio scouring-direct second bath dyeing.

\subsection{Conventional Scouring}

Pre wetted fabric was conventionally scoured using $2.5 \%$ sodium hydroxide, $1.5 \%$ sodium carbonate \& $0.5 \%$ detergent at $100^{\circ} \mathrm{C}$ for a period of 2 hrs, 4 hrs, 6 hrs and 8 hrs.

\subsection{Bleaching}

Conventionally scoured fabric was bleached using $0.7 \%$ hydrogen per oxide, $1 \%$ stabilizer at a $\mathrm{pH} 10.5$ at $80^{\circ} \mathrm{C}$ for a period of 2 hrs.

\subsection{Dyeing}

Bio-scoured and conventionally scoured and bleached fabric after neutlization were dyed with C.I Reactive 24 red to produce 5\% shade. The following test methods are listed in Table 2 to assess the process performance of the fabrics under study.

\section{Results \& Discussion}

Effects of concentration of enzyme, temperature, $\mathrm{pH} \&$ duration on the properties of bio scoured fabric have been studied.

1) Effect of concentration of enzyme Indo biosoft on absorbency of fabric

The effect of concentration of Indo biosoft on absorbency has been studied by varying the concentration from $1 \%, 3 \%$ \& $5 \%$ at $80^{\circ} \mathrm{C}$ for 1 hour (Table 3).

2) Effect of temperature of scouring bath on absorbency

The effect of temperature on absorbency has been studied by varying temperature from $40^{\circ} \mathrm{C}, 60^{\circ} \mathrm{C}$ and $80^{\circ} \mathrm{C}$ keeping concentration of enzyme $5 \%$ \& treatment time 1 hour. The effect of temperature of scouring bath on absorbency is presented in Table 4

3) Effect of $\mathrm{pH}$ of scouring bath on absorbency

The effect of $\mathrm{pH}$ on absorbency has been studied by varying $\mathrm{pH}$ from 5.5, 7.0 \& 8.5, keeping concentration of enzyme 5\% \& treatment time 1 hour. The results are indicated in Table 5.

4) Effect of duration of scouring bath on absorbency

The effect of duration on absorbency has been studied by varying temperature from 30 min, 45 min \& 1 hour. 
Table 2. Testing and analysis.

\begin{tabular}{ccc}
\hline Sino & Test & Method/Instrument \\
\hline 1 & Absorbency & IS 2349-1963 \\
2 & K/S value & Macbeth colour Eye CE 3000 spectra photometer \\
3 & $\mathrm{pH}$ & $\mathrm{pH}$ meter \\
4 & $\mathrm{TDS}$ & TDS meter \\
5 & BOD \& COD & Titrimetric method \\
6 & Washing fastness & As per ISO-3 recommendation (Laundero meter) \\
7 & Rubbing fastness & IS-766-1956 (Crpck meter) \\
\hline
\end{tabular}

Table 3. Effect of concentration of Indo Biosoft on absorbency.

\begin{tabular}{cc}
\hline Concentration of enzyme (\% o.w.f) & Absorbency (Seconds) \\
\hline $1 \%$ & 12 \\
$3 \%$ & 4 \\
$5 \%$ & 1 \\
\hline
\end{tabular}

Table 4. Effect of temperature of scouring bath on absorbency.

\begin{tabular}{cc}
\hline Temperature scouring bath $\left({ }^{\circ} \mathbf{C}\right)$ & Absorbency (Seconds) \\
\hline 40 & 18 \\
60 & 8 \\
80 & 1 \\
\hline
\end{tabular}

Table 5. Effect of $\mathrm{pH}$ of scouring bath on absorbency.

\begin{tabular}{cc}
\hline $\mathbf{p H}$ & Absorbency (Seconds) \\
\hline 5.5 & 1 \\
7.0 & 2 \\
8.0 & 1 \\
\hline
\end{tabular}

keeping concentration of enzyme $5 \%$ \& treatment temperature $80^{\circ} \mathrm{C}$ (Table 6).

\section{Comparative Study on Effect of Bio scouring (Indo Biosoft \& Conventionally Scoured \& Bleached Fabrics}

1) Effect of pre-treatment on fabric shrinkage

The effect of pre-treatment on fabric shrinkage is presented in Table 7. The shrinkage value of Indo biosoft process is lower than conventional process. It is strongly believe that the chemicals used in conventional method reduce the hydrogen bond strength in the tensile direction of the fabric.

2) Effect of pre-treatment on fabric weight loss

Table 8 clearly indicated that the fabric treated in conventional pre-treatment process is much higher than Indo biosoft bio scour process. Higher weight loss in traditional method may be due to severity of treatment, which results in greater removal of natural and added impurities. There is also the possibility of degradation of cellulose because of harsher alkaline treatment. Enzymatic processing shows lower weight loss and this may be due to controlled treatment.

3) Effect of pre-treatment on wax content of the fabric

It can be seen from Table 9 that the wax content of the conventional pre-treated fabric is lower than Indo biosoft process. This is due to severe saponification action of caustic used in conventional process. 
Table 6. Effect of duration of scouring bath on absorbency.

\begin{tabular}{cc}
\hline Duration of treatment (minutes) & Absorbency (Seconds) \\
\hline 30 & 18 \\
45 & 8 \\
60 & 1 \\
\hline
\end{tabular}

Table 7. Effect of pre-treatment on fabric shrinkage.

\begin{tabular}{cc}
\hline Treatment & Shrinkage (\%) \\
\hline Conventionally scoured \& bleached & 6 \\
Bio scour (Indo Biosoft) & 2.2 \\
\hline
\end{tabular}

Table 8. Effect of pre-treatment on fabric weight loss.

\begin{tabular}{cc}
\hline Treatment & Weight loss (\%) \\
\hline Conventionally scoured \& bleached & 6.0 \\
Bio scour (Indo Biosoft) & 1.8 \\
\hline
\end{tabular}

Table 9. Effect of pre-treatment on wax content of the fabric.

\begin{tabular}{cc}
\hline Treatment & Wax content (\%) \\
\hline Conventionally scoured \& bleached & 0.2 \\
Bio scour (Indo Biosoft) & 0.3 \\
Original sample & 0.7 \\
\hline
\end{tabular}

4) Effect of bio scouring on process sequence

It can be seen from Table 10 that the process sequence in conventional process is much greater than Indo biosoft process. It is strongly believe that the number of washing sequence in convectional process is more than bio scour process. This is due to low chemical trace in bio scour process. Moreover, Indo biosoft process is carried out in neutral $\mathrm{pH}$ which makes the process free from alkaline on fabric surface consequently no need of acid neutralization process.

5) Comparative study on Properties of dyed fabric

As shown in Table 11, fabric sample processed by Indo biosoft bio scour methods have shown higher performancerating in wash fastness, rubbing fastness and light fastness properties in comparison to traditional method. This may be due to better fixation of dyes in the substrate.

6) Economic benefits of bio scour (Indo biosoft) over conventional Pre treatment process

Economics for each process was calculated considering all the details like chemicals, auxiliaries, water, electricity and labor costs, and tabulated in Tables 12-14. It is observed that cost of processing fabric in traditional method is around $1.32 \mathrm{USD} / \mathrm{Kg}$, whereas costs of one stage enzymatic processed fabric was $0.5 / \mathrm{Kg}$ USD respectively. The net cost saving in enzymatic process is $0.82 \mathrm{USD} / \mathrm{Kg}$.

\section{Economic Advantages of Enzymatic Process (Pre-Treatment Process only Considered)}

\subsection{Fabric Weight $4000 \mathrm{Kg}$}

It is found in Table 15 that the effluent resulting from conventional process has higher values in all the aspects studied. This is due to heavy chemical usage in conventional process. The main culprit in conventional process is caustic which is responsible to increase TDS and COD values in the effluent. The effluent from Indo biosoft was reasonably lower in pollution load thereby making it very beneficial. The reason was found that the enzymatic process was totally free from alkaline and acid treatment. 
Table 10. Effect of bio scouring on process sequence.

\begin{tabular}{ccc}
\hline Treatment & Bio Scour (Indo Bio soft) & Conventional Pre-treatment \\
Scouring & Elimination of caustic & Caustic using \\
Washing & Eliminated & Washing is compulsory \\
Bleaching & $\begin{array}{c}\text { Elimination of bleaching for } \\
\text { medium to dark colours }\end{array}$ & Bleaching is vital \\
Acid neutralization & Eliminated & Acid neutralization is necessary \\
Washing & Eliminated & Washing is compulsory \\
Per-oxide killer & Eliminated & Compulsory \\
Washing & Eliminated & Compulsory \\
Total number of process sequence before dyeing & 1 & 8 \\
\hline
\end{tabular}

Table 12. Costing details of conventional process.

\begin{tabular}{ccccc}
\hline Chemicals & Consumption by \% & $\begin{array}{c}\text { Consumption by } \\
\text { Quantity }\end{array}$ & Unit Cost in USD & Total Cost in USD \\
\hline Per-oxide & 4 & 168 liters & 1.50 & 252.0 \\
Caustic & 3 & $126 \mathrm{Kg}$ & 0.80 & 100.8 \\
Stabilizer & 0.4 & $16.8 \mathrm{Kg}$ & 1.40 & 23.52 \\
softener & 0.2 & 8.4 & 3.0 & 25.2 \\
Acetic Acid & 1.5 & 50.4 liters & 0.9 & 90.72 \\
Soap & 1 & 40 liters & Total cost & $\mathbf{5 2 8 . 2 4}$ \\
& & & Cost/1 KG & $\mathbf{1 . 3 2}$ \\
\hline
\end{tabular}

Table 13. Costing details of bio scour (Indo Biosoft) process.

\begin{tabular}{ccccc}
\hline Chemicals & Consumption by \% & $\begin{array}{c}\text { Consumption by } \\
\text { Quantity }\end{array}$ & Unit Cost in USD & Total Cost in USD \\
\hline Bio scouring & $3.5 \%$ & $140 \mathrm{~kg}$ & 1.3 & 182.0 \\
& & Total cost & $\mathbf{1 8 2 . 0}$ \\
& & Cost $\mathbf{1}$ Kg & $\mathbf{0 . 0 5}$ \\
\hline
\end{tabular}

Table 14. Cost difference between conventional and bio scour pre-treatment process (chemical cost only).

\begin{tabular}{ccc}
\hline SI. NO & Process & Cost/Kg USD \\
\hline $\mathbf{1}$ & Conventional Process & 1.32 \\
$\mathbf{2}$ & Enzymatic process & 0.05 \\
& Net cost saving (Chemical cost only) & $\mathbf{1 . 2 7}$ \\
\hline
\end{tabular}

\subsection{Total Requirement for $1000 \mathrm{Kgs}$}

It is observed from Table 16 that energy, time and water consumption of traditional method is higher than Indo biosoft enzymatic methods. This is due to short sequence process in Indo biosoft process when compared to conventional process. Elimination of washing process helps to save substantial amount of water in Indo biosoft process. It is quite obvious that the number of machine operation is reduced thereby considerable energy and time saving.

Table 17 clearly indicates that the overall process cost of Indo biosoft is much lower than conventional 
Table 15. Analysis of existing and bio processed effluents.

\begin{tabular}{cccc}
\hline SI. NO & Parameters & $\begin{array}{c}\text { Raw Effluent } \\
\text { Existing Process }\end{array}$ & $\begin{array}{c}\text { Raw Effluent } \\
\text { Bio Process }\end{array}$ \\
\hline 1 & $\mathrm{pH}$ & 11.4 & 6.8 \\
2 & Color & Intense 480 & HAZEN 310 \\
3 & Total suspended solids & 380 & 30 \\
4 & Total dissolved soilds & 4600 & 2500 \\
5 & Chemical oxygen demand & 3400 & 1600 \\
\hline
\end{tabular}

Table 16. Analysis of water, time and energy requirements for pretreatment of knitted fabric using existing and bio processing.

\begin{tabular}{cccc}
\hline SI. NO & Particulars & Existing Process & Bio Processing \\
\hline 1 & Time & $1 \mathrm{hr} .45 \mathrm{~min}$ & $1 \mathrm{hr}$ \\
2 & Energy requirement & 58.21 & 20.88 \\
3 & Water requirement & 40,000 liters & 20,000 liters \\
4 & Total cost (energy, water and effluent treatment ) & 39.68 USD & 22.22 USD \\
\hline
\end{tabular}

Table 17. Overall cost difference between conventional and bio scour pre-treatment process (energy, water, chemical and effluent treatment).

\begin{tabular}{|c|c|c|c|}
\hline SI. NO & Particulars & $\begin{array}{c}\text { Existing Process } \\
\text { USD }\end{array}$ & $\begin{array}{c}\text { Bio Processing } \\
\text { USD }\end{array}$ \\
\hline 1 & Chemicals & 1.32 & 0.05 \\
\hline 2 & Total cost (Energy, Water and Effluent treatment) & 0.04 . & 0.02 \\
\hline \multirow[t]{2}{*}{3} & Total cost & 1.36 & 0.07 \\
\hline & Net cost saving/Kg & 1.29 & \\
\hline
\end{tabular}

process. The reason is that the consumption of chemicals and auxiliaries, energy and utilities requirement in Indo biosoft process is much lower than conventional process.

\section{Conclusion}

Cotton fabrics processed with enzymes which have shown better color fastness properties are observed in the subjective assessment, enzymatic processes have registered better hand feeling than traditional method. Optimum condition, bio scouring with Indo biosoft, requires treatment with $5 \%$ at $\mathrm{pH} 5.5$ at $80^{\circ} \mathrm{C}$ for 1 hour. Conventional scouring produces excellent whiteness causing more shrinkage of fabrics. Conventional scouring shows more weight loss than bio scouring. Due to dull whiteness, bio scouring fabric is more suitable for medium to dark color than light \& bright shade. The volume of effluent generated by bio scouring is $40 \%$ less as compared to conventional pre-treatment process. Significant saving of water due to lower water consumption in bio scouring method of enzymatic processes exerts less effluent load on environment. Economics also do favor enzymatic process. Considering better durability, fastness, feel of the fabric, and environment friendly processing, enzymatic process may be preferred for the betterment of World Textile Industries.

\section{References}

[1] Boyer, P.D. (2011) The Enzymes. 3rd Edition, Vol. 5, Academic Press Inc., New York.

[2] Petry, G.M.B.H. (2001) Application of Enzyme in the Textile Industry. NCM, 15, 23-28.

[3] Briggs, G.E. and Haldane, J.B.S. (1925) A Note on the Kinetics of Enzyme Action. Biochemical Journal, 19. 
[4] (2005) A Text Book of Biotechnology. S. Chand \& Company Press.

[5] Fornelli Saverio (1995) The personal enzyme Horoscope. ITB Dyeing/Printing/Finishing $3^{\text {rd }}$ Q 41,62-65.

[6] Buschie, D.G. and Yang, X.D. (2001) Enzymatic Bleaching of Cotton Fabric with Glucose Oxidase. Textile Research Journal, 71, 388-394. http://dx.doi.org/10.1177/004051750107100504

[7] Chelikani, P., Fita, I. and Loewen, P.C. (2004) Diversity of Structures and Properties among Catalases. Cellular and Molecular Life Sciences, 61, 192-208. http://dx.doi.org/10.1007/s00018-003-3206-5

[8] Svendsen, A. (2000) Lipase Protein Engineering. Biochimica et Biophysica Acta (BBA)_Protein Structure and Molecular Enzymology, 1543. http://dx.doi.org/10.1016/s0167-4838(00)00239-9

[9] Barrett, A.J., Rawlings, N.D. and Woessner, J.F. (2003) The Handbook Of Proteolytic Enzymes. Academic Press.

[10] Shrivastava, M. and Sanghi, R. (2005) Chemistry of Green Environment. Narosa Publishing House.

[11] Cavaco-Paulo, A. and Gubitz, G.M. (2003) Textile Processing with Enzymes. Woodhead Publishing Limited. 